\title{
VILNIAUS GEDIMINO TECHNIKOS UNIVERSITETO PIRMO KURSO STUDENTŲ POŽIŪRIO İ KŪNO KULTŪRĄ YPATUMAI
}

\author{
Stanislavas Dadelo, Povilas Tamošauskas, Valda Morkūnienė, Daiva Višinskienė \\ Vilniaus Gedimino technikos universitetas, Vilnius, Lietuva
}

\begin{abstract}
Stanislavas Dadelo. Docentas socialinių mokslų daktaras. Vilniaus Gedimino technikos universiteto Kūno kultūros katedros docentas. Moks-
\end{abstract} linių tyrimų kryptis — specialus profesinis fizinis rengimas, studentų fizinio rengimo aspektai.

\section{SANTRAUKA}

Vilniaus Gedimino technikos universiteto studentu (merginu ir vaikinu), istojusiu i pirma kursa, požiūrio i kūno kultūra bei santykio su ja tyrimas, šio požiūrio skirtumu nustatymas padès efektyviau organizuoti ir optimizuoti kūno kultūros pratybas, ugdys poreikị sistemingai fiziškai judèti.

Tyrimo tikslas - išsiaiškinti VGTU pirmo kurso studentu požiūrị z kūno kultūrq ir santyki su ja, atskleisti skirtumus.

Buvo tiriami 2181 19-20 metu amžiaus studentai, $2007 \mathrm{~m}$. istoję i VGTU pirma kursq (merginu $(n=733)$ ir vaikinu $(n=1448))$. Tiriamaja imti sudare $73 \%$ visu pirmo kurso studentu. Tiriamieji atrinkti taikant atsitiktinés atrankos metoda. Tyrimo metu taikytas anketinès apklausos raštu metodas. Anketa sudaryta ǐs 10 klausimu su pateiktais galimais atsakymu variantais. Dalis klausimu buvo uždari (galima rinktis tiktai vienq iš pateiktu atsakymu variantu), dalis - atviri (galima rinktis kelis iš pateiktu atsakymu arba pateikti savo varianta). Apklausiama buvo laikantis tiriamuju anonimiškumo, informavimo apie tyrimo tiksla bei eiga principu. Tyrimas atliktas ivadinès paskaitos metu.

Daugumos i VGTU ìstojusiu studentu santykis su fiziniu aktyvumu skirtingas, tai patvirtino mūsu iškelta hipotezę. Merginos ir vaikinai skirtingai vertina küno kultüra mokykloje. Merginu ir vaikinu motyvai sportuoti yra iš esmès skirtingi, išryškejo studentu savarankiškumo didëjimo tendencijos, noras savarankiškai fiziškai mankštintis. Todèl kūno kultüros organizavimas ir taikomi küno kultūros ugdymo metodai vaikinams ir merginos turi skirtis. Studentams dar labai trūksta kūno kultūros teorijos žiniu, praktiniu igūdžiu. Panaudojant atlikto tyrimo duomenis, gausia moksline metodinę medžiaga, atsiras geros prielaidos ugdyti VGTU studentu fizinì aktyvuma, ypač ju fizinę saviugda, teikti daugiau dalykiniu ir metodiniu žiniu.

Raktažodžiai: studentu požiūris į kūno kultūra, fizinis aktyvumas, fizinè saviugda.

\section{IVADAS}

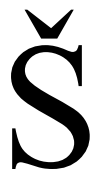

iuolaikiniame technizacijos amžiuje labai pasikeite žmogaus fizinis aktyvumas. Žmonès dirbdami daugiausia sėdi arba užima pasyvią statinę būseną. Per daugeli žmogaus organizmo vystymosi metų susiformavo poreikis aktyviai fizinei veiklai. Fiziškai nejudant, žmogaus organizme vyksta sudètingi deadaptaciniai reiški- niai - nyksta atskiri organai ir sistemos, sutrinka jų funkcijos, atsiranda struktūrinių ir funkcinių pokyčiu, galinčiu trikdyti normalią žmogaus egzistenciją (Willmore, Costill, 1994; Платонов, 1988). Moksleivių, studentų santykis su kūno kultūra, jų fizinis aktyvumas pastaraisiais metais plačiai nagrinėjamas (Dadelo, 2000; Poteliūniené, 2001; 
Tubelis, 2001; Laker, 2002; Tamošauskas ir kt., 2004; Tamošauskas, 2006). Visgi pereinamuoju laikotarpiu, moksleiviams tapus studentais, pakinta gyvensenos sąlygos, keičiasi ir asmens vertybiu sistema. Vyresnių klasių vaikinu ir merginu gyvensenos skiriamieji bruožai pakankamai ryškūs (Puišienè ir kt., 2008), tačiau jų santykis su kūno kultūra nèra aiškus.

Studentams įstojus i aukštąsias mokyklas, pasikeičia jų gyvenimo būdas, dienotvarkè, didejja protinès veiklos krūvis, sumažèja judamoji veikla. Išlaikyti gerą sveikatos lygi, fizini išsivystymą ir parengtumą bei funkcini pajègumą reikiamo lygio darosi sudètinga. Tik gerai organizuotos kūno kultūros pratybos ir sąmoninga, gera metodika pagrista fizinè saviugda gali padèti studentams visavertiškai gyventi šiuolaikinèmis sąlygomis (Dadelo, 2000; Tubelis, 2001). Šiuo kompiuterizacijos ir technizacijos laikotarpiu, kai studentų kasdieniame gyvenime išryškèja hipokinezės procesai, organizme vyksta deadaptaciniai procesai, svarbu išsiaiškinti būdus, galinčius paveikiai kompensuoti fizinio aktyvumo trūkumą. Šios problemos nagrinėjimui reikia pasitelkti sporto mokslo priemones ir metodus. Tyrinèjant žmogų, jo elgseną, būtina pasitelkti kuo daugiau tyrimo metodų iš ivvairių mokslo sričiu (Prigogine, 1997; Kauffman, 2000; Skernevičius ir kt., 2004).

Studentu fizinio aktyvumo subalansavimo problemos sprendimą reikètu pradèti nuo pirmo kurso studentų požiūrio ị kūno kultūrą ir jų fizinio aktyvumo bei sportavimo ypatumų tyrimo. Panašiu tyrimu Lietuvos aukštosiose mokyklose jau yra atlikta (Poteliūnienè ir kt., 2003). Lietuvos aukštosios mokyklos dirba pagal skirtingas studiju programas, puoselèja ịvairias tradicijas, bet dažnai per mažai dèmesio skiriama studentų kūno kultūros plètotei. Vilniaus Gedimino technikos universiteto (VGTU) studentų, istojusių i pirmą kursą, požiūris i kūno kultūrą ir santykis su ja yra ištirti nepakankamai. Nèra ištyrinèti vaikinų ir merginų fizinio aktyvumo išskirtiniai bruožai.

Darome hipotetinę prielaidą, kad VGTU studentų (merginu ir vaikinų), istojusiu i pirmą kursą, požiūrio į kūno kultūrą bei santykio su ja tyrimu išryškès merginu ir vaikinu skiriamieji bruožai šiuo klausimu, ir tai turètu padèti paveikiau organizuoti ir optimizuoti kūno kultūros pratybas.

Tyrimo tikslas - išsiaiškinti VGTU pirmo kurso studentų požiūri i kūno kultūrą bei santyki su ja, atskleisti merginu ir vaikinu skiriamuosius bruožus šiuo klausimu.

Tyrimo organizavimas. Buvo tiriami 2181 19-20 metų amžiaus studentai, 2007 m.isstoję i
VGTU pirmą kursą (merginu $(\mathrm{n}=733)$ ir vaikinų $(n=1448))$. Tiriamaja imti sudare $73 \%$ visu pirmo kurso studentų. Tiriamieji atrinkti taikant atsitiktinès atrankos metodą. Tyrimo metu taikytas anketinès apklausos raštu metodas, modifikuotas tyrimais aprobuotos anketos (Poteliūnienè ir kt., 2003) variantas. Anketa sudaryta iš 10 klausimų ir pateikti galimi atsakymų variantai. Dalis klausimu buvo uždari (galima rinktis tiktai vieną iš pateiktu atsakymų variantu), dalis - atviri (galima rinktis kelis iš pateiktų atsakymų arba pateikti savo variantą)

Tyrimo eiga. Tiriamieji apklausti laikantis anonimiškumo, informuoti apie tyrimo tikslą ir eigą. Tyrimas atliktas ìvadinès paskaitos metu. Statistiné tyrimo duomenu analizè atlikta naudojant Microsoft Office Excel programa. Vertinat skirtumus tarp dviejų nepriklausomu imčių, apskaičiuotas chi kvadrato $\left(\chi^{2}\right)$ kriterijus. Skirtumo patikimumas laikytas reikšmingu, kai $\mathrm{p}<0,05$.

\section{REZULTATAI}

Atliktas tyrimas parodè, kad merginų ir vaikinų požiūris i fizini aktyvumą skiriasi, nevienodai jie taiko ir kūno kultūros priemones savo gyvenime. Mokykloje kūno kultūros pamokos patiko $77 \%$ vaikinu ir tik $58 \%$ merginu $\left(\chi^{2}=86,88\right.$; $\mathrm{p}<0,05)$. Didžiausias vaidmuo formuojant požiūri i kūno kultūrą atitenka mokytojui. Mokytojo vaidmeni ugdant teigiamą požiūrị i kūno kultūrą labiau vertina merginos $\left(\chi^{2}=7,49 ; \mathrm{p}<0,05\right)$ (1 lent.). Tačiau vertinant mokytojo indèli $\mathfrak{i}$ kūno kultūros pratimų išmokimą merginų ir vaikinų atsakymuose vyrauja neigiami vertinimai. $61 \%$ vaikinų ir daug mažiau (48\%) merginu $\left(\chi^{2}=33,82\right.$; $\mathrm{p}<0,05)$ teigia, kad mokytojai neišmoke jų savarankiškai atlikti rytinę mankštą, o kad pakankamai gerai išmoké, teigia vienodas procentas (14\%) merginų ir vaikinu (1 pav.). Teigini, kad mokytojai neišmokè savarankiškai treniruotis, patvirtino taip pat daugiau vaikinu negu merginu $\left(\chi^{2}=4,04 ; p<0,05\right)(2$ pav.). Teigini, kad mokykla padèjo formuoti pozityvų požiūri i kūno kultūrą, patvirtino vienoda procentinè dalis merginu ir vaikinu (po $40 \%$ ).

Pozityviam, kryptingam fiziniam aktyvumui nepakanka teigiamai vertinti kūno kultūrą, reikia žinių, mokejimų, igūdžių, geros motyvacijos. Kad turi pakankamai fizinio aktyvumo žiniu ir suformuotu igūdžių, atsake tiktai trečdalis apklaustų studentú, o studenčių dar mažiau - tiktai $21 \%\left(\chi^{2}=9,90 ; p<0,05\right)$. Tačiau daugiau žinoti 


\begin{tabular}{|c|c|c|c|c|c|c|}
\hline \multirow{19}{*}{$\begin{array}{l}1 \text { lentelè. VGTU pirmo } \\
\text { kurso studentų požiū- } \\
\text { ris ị kūno kultūrą mo- } \\
\text { kykloje }\end{array}$} & \begin{tabular}{|l} 
Ar Jums patiko kūno kultūra \\
mokykloje?
\end{tabular} & $\begin{array}{l}\text { Absoliučios ir pro- } \\
\text { centinės reikšmès }\end{array}$ & Vaikinai & Merginos & Iš viso & $\chi^{2}$ ir p reikšmès \\
\hline & \multirow{2}{*}{ Taip } & $\mathrm{n}$ & 1118 & 423 & 1541 & \multirow{4}{*}{$\begin{array}{l}\chi^{2}=86,88 \\
p<0,05\end{array}$} \\
\hline & & $\%$ & 77 & 58 & 71 & \\
\hline & \multirow{2}{*}{$\mathrm{Ne}$} & $\mathrm{n}$ & 330 & 310 & 640 & \\
\hline & & $\%$ & 23 & 42 & 29 & \\
\hline & \multirow{2}{*}{ Iš viso } & $\mathrm{n}$ & 1448 & 733 & 2181 & \\
\hline & & $\%$ & 100 & 100 & 100 & \\
\hline & Jei patiko, tai kodèl? & $\begin{array}{l}\text { Absoliučios ir pro- } \\
\text { centinès reikšmès }\end{array}$ & Vaikinai & Merginos & Iš viso & $\chi^{2}$ ir $\mathbf{p}$ reikšmès \\
\hline & \multirow{2}{*}{ Nèra atsakymo } & $\mathrm{n}$ & 223 & 310 & 533 & $\chi^{2}=180,59$ \\
\hline & & $\%$ & 13 & 36 & 21 & $\mathrm{p}<0,05$ \\
\hline & \multirow{2}{*}{ Geri mokytojai } & $\mathrm{n}$ & 394 & 241 & 635 & $\chi^{2}=7,49$ \\
\hline & & $\%$ & 24 & 28 & 25 & $\mathrm{p}<0,05$ \\
\hline & \multirow{2}{*}{ Gera programa } & $\mathrm{n}$ & 295 & 180 & 475 & $\chi^{2}=4,93$ \\
\hline & & $\%$ & 18 & 21 & 19 & $\mathrm{p}<0,05$ \\
\hline & \multirow{2}{*}{ Gera sporto bazè, inventorius } & $\mathrm{n}$ & 253 & 117 & 370 & $\chi^{2}=0,79$ \\
\hline & & $\%$ & 15 & 14 & 15 & $\mathrm{p}>0,05$ \\
\hline & \multirow{2}{*}{ Kita } & $\mathrm{n}$ & 502 & 13 & 515 & \multirow{2}{*}{$\begin{array}{l}\chi^{2}=397,57 \\
p<0,05\end{array}$} \\
\hline & & $\%$ & 30 & 2 & 20 & \\
\hline & Iš viso & $\mathrm{n}$ & 1667 & 861 & 2528 & \\
\hline
\end{tabular}

2 lentelè. VGTU pirmo kurso studentų savarankiško sportavimo rodikliai

\begin{tabular}{|c|c|c|c|c|c|}
\hline $\begin{array}{l}\text { Kiek valandų per savaitę } \\
\text { savarankiškai sportuojate? }\end{array}$ & $\begin{array}{l}\text { Absoliučios ir pro- } \\
\text { centinės reikšmės }\end{array}$ & Vaikinai & Merginos & Iš viso & $\chi^{2}$ ir p reikšmès \\
\hline \multirow{2}{*}{ Nesportuoju } & $\mathrm{n}$ & 58 & 227 & 285 & \multirow{2}{*}{$\begin{array}{l}\chi^{2}=296,89 \\
p<0,05\end{array}$} \\
\hline & $\%$ & 4 & 31 & 13 & \\
\hline \multirow{2}{*}{ Iki $2 \mathrm{~h}$} & $\mathrm{n}$ & 662 & 301 & 963 & \multirow{2}{*}{$\begin{array}{l}\chi^{2}=4,29 \\
p<0,05\end{array}$} \\
\hline & $\%$ & 46 & 41 & 44 & \\
\hline \multirow{2}{*}{ Iki $3 \mathrm{~h}$} & $\mathrm{n}$ & 306 & 128 & 434 & \multirow{2}{*}{$\begin{array}{l}\chi^{2}=4,18 \\
p<0,05\end{array}$} \\
\hline & $\%$ & 21 & 17 & 20 & \\
\hline \multirow{2}{*}{$4 \mathrm{~h}$ ir daugiau } & $\mathrm{n}$ & 422 & 77 & 499 & \multirow{2}{*}{$\begin{array}{l}\chi^{2}=105,78 \\
p<0,05\end{array}$} \\
\hline & $\%$ & 29 & 11 & 23 & \\
\hline \multirow{2}{*}{ Iš viso } & $\mathrm{n}$ & 1448 & 733 & 2181 & \\
\hline & $\%$ & 100 & 100 & 100 & \\
\hline
\end{tabular}

3 lentelè. VGTU pirmo kurso studenty savarankiško sportavimo motyvai

\begin{tabular}{|c|c|c|c|c|c|}
\hline $\begin{array}{l}\text { Kokie motyvai lėmė Jūsų norą } \\
\text { savarankiškai sportuoti arba } \\
\text { lankyti organizuotas pratybas? }\end{array}$ & $\begin{array}{l}\text { Absoliučios ir pro- } \\
\text { centinės reikšmės }\end{array}$ & Vaikinai & Merginos & Iš viso & $\chi^{2}$ ir p reikšmès \\
\hline \multirow{2}{*}{ Jokie } & $\mathrm{n}$ & 93 & 193 & 286 & \multirow{2}{*}{$\begin{array}{l}\chi^{2}=159,13 \\
p<0,05\end{array}$} \\
\hline & $\%$ & 4 & 14 & 8 & \\
\hline \multirow{2}{*}{ Noras būti fiziškai stipriam } & $\mathrm{n}$ & 725 & 190 & 915 & \multirow{2}{*}{$\begin{array}{l}\chi^{2}=120,54 \\
p<0,05\end{array}$} \\
\hline & $\%$ & 31 & 14 & 25 & \\
\hline \multirow{2}{*}{ Noras turèti gražų kūną } & $\mathrm{n}$ & 380 & 335 & 715 & \multirow{2}{*}{$\begin{array}{l}\chi^{2}=229,65 \\
p<0,05\end{array}$} \\
\hline & $\%$ & 16 & 25 & 20 & \\
\hline \multirow{2}{*}{$\begin{array}{l}\text { Noras stiprinti sveikatą ir } \\
\text { likviduoti fizinio išsivystymo } \\
\text { trūkumus (laikyseną, stuburo } \\
\text { iškrypimus ir kt.) }\end{array}$} & $\mathrm{n}$ & 303 & 204 & 507 & \multirow{2}{*}{$\begin{array}{l}\chi^{2}=12,76 \\
p<0,05\end{array}$} \\
\hline & $\%$ & 13 & 15 & 14 & \\
\hline \multirow{2}{*}{$\begin{array}{l}\text { Atnaujinti jègas po itempto } \\
\text { protinio darbo }\end{array}$} & $\mathrm{n}$ & 314 & 154 & 468 & \multirow{2}{*}{$\begin{array}{l}\chi^{2}=63,03 \\
p<0,05\end{array}$} \\
\hline & $\%$ & 14 & 11 & 13 & \\
\hline \multirow{2}{*}{$\begin{array}{l}\text { Išsiugdyti charakteri, valią, } \\
\text { atkaklumą ir pan. }\end{array}$} & $\mathrm{n}$ & 267 & 127 & 394 & \multirow{2}{*}{$\begin{array}{l}\chi^{2}=0,41 \\
p>0,05\end{array}$} \\
\hline & $\%$ & 12 & 9 & 11 & \\
\hline \multirow{2}{*}{$\begin{array}{l}\text { Noras būti fiziškai ir dvasiškai } \\
\text { harmoningam }\end{array}$} & $\mathrm{n}$ & 131 & 107 & 238 & \multirow{2}{*}{$\begin{array}{l}\chi^{2}=14,84 \\
p<0,05\end{array}$} \\
\hline & $\%$ & 6 & 8 & 6 & \\
\hline \multirow{2}{*}{$\begin{array}{l}\text { Noras siekti didelių sportinių } \\
\text { rezultatų }\end{array}$} & $\mathrm{n}$ & 104 & 36 & 140 & \multirow{2}{*}{$\begin{array}{l}\chi^{2}=4,36 \\
p<0,05\end{array}$} \\
\hline & $\%$ & 4 & 3 & 4 & \\
\hline Iš viso & $\mathrm{n}$ & 2317 & 1346 & 3663 & \\
\hline
\end{tabular}

nori kur kas didesnė dalis merginų negu vaikinu $\left(\chi^{2}=32,71 ; p<0,05\right)$ (3 pav.). Tokiu studentu, kurie visiškai neturi supratimo, kaip tinkamai sportuoti, yra nedaug: vaikinu $-13 \%$, merginų tik $7 \%\left(\chi^{2}=20,17 ; p<0,05\right)$. Nors dauguma studentu neturi supratimo, kaip tinkamai sportuoti ir spor- 


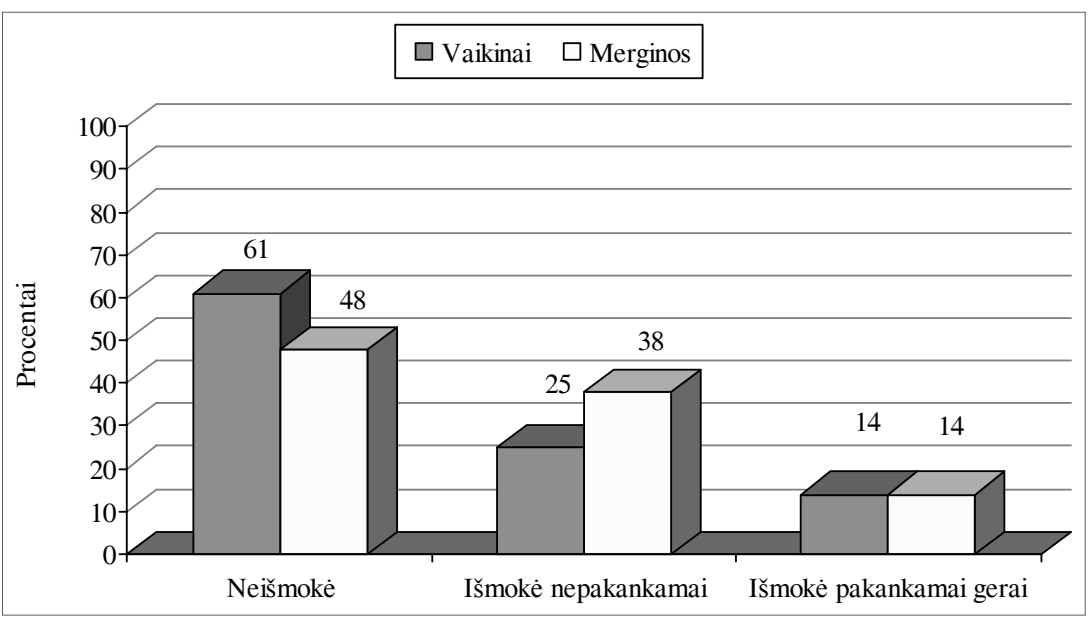

1 pav. Atsakymų i klausimą Ar kūno kultūros mokytojas Jus išmoke savarankiškai atlikti rytinę mankštą? raiška tiriamųjų grupèse

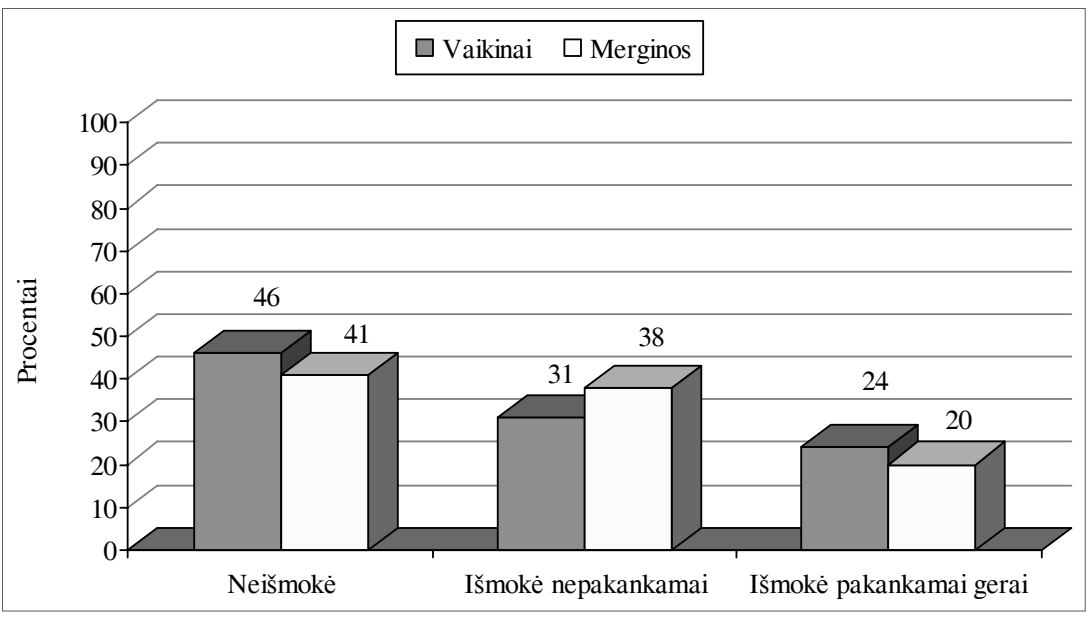

2 pav. Atsakymu i klausimą $A r$ kūno kultūros mokytojas Jus išmoke savarankiškai treniruotis? raiška tiriamųjų grupèse

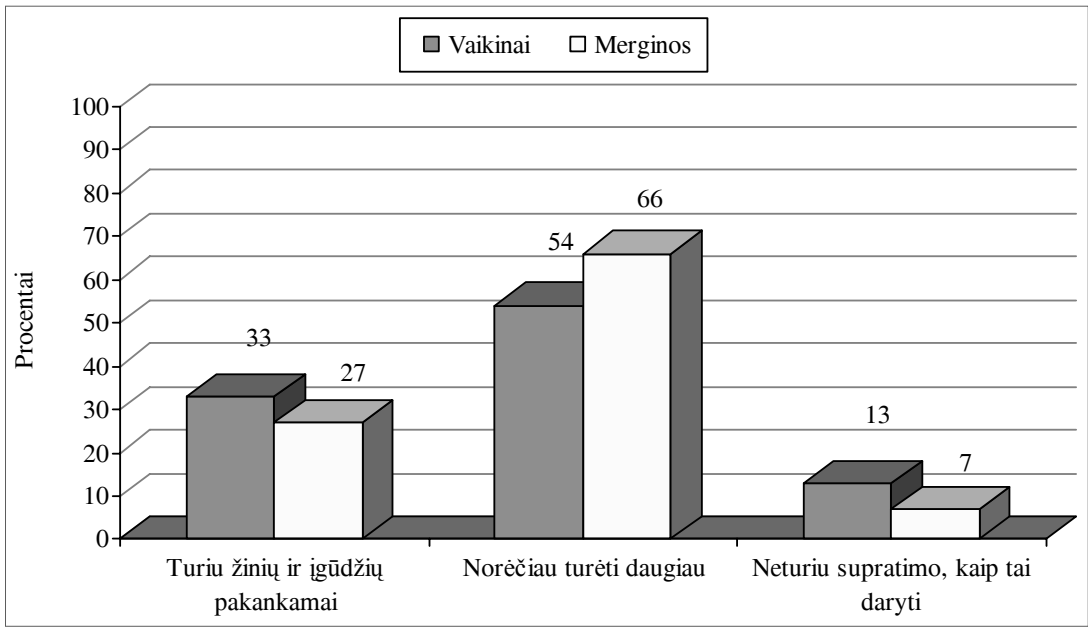

3 pav. Atsakymų i klausimą Ar pakanka žiniụ ir igūužiu metodiškai tinkamai sportuoti? raiška tiriamųjų grupèse

tavimo igūdžių, bet didelè jų dalis (maždaug tiek pat merginu ir vaikinu) pareiškè, kad savarankiškai sportuoja (4 pav.). 34\% vaikinų pareiškè, kad lanko organizuotas sporto pratybas, o merginų šis rodiklis yra daug mažesnis - 21\% $\left(\chi^{2}=47,13\right.$; $\mathrm{p}<0,05)$.

Daugiausia vaikinų savarankiškai sportuoja po $2 \mathrm{~h}$ per savaitę $(46 \%)$, merginų šis rodiklis statistiškai patikimai mažesnis $(\mathrm{p}<0,05)$ (2 lent.). Po $3 \mathrm{~h}$ per savaitę merginų sportuoja taip pat mažiau, o po $4 \mathrm{~h}$ per savaitę - merginų tik $11 \%$, vaikinų $29 \%$. Tai rodo, kad gana didelè dalis vaikinų skiria daug laiko savo fizinei sveikatai ir fiziniam pajègumui gerinti.

Analizuojant priežastis, lèmusias norą savarankiškai sportuoti arba lankyti organizuotas pratybas, matyti (3 lent.), kad vaikinai pagrindine priežastimi laiko norą būti fiziškai stipriems - 31\%, tuo tarpu šią priežasti paminėjo tiktai $14 \%$ merginų. Merginų pagrindinis motyvas sportuoti buvo noras turèti gražų kūną, ir tai sudare $25 \%$, vaikinams šis motyvas yra mažiau svarbus - $16 \%\left(\chi^{2}=229,65\right.$; $\mathrm{p}<0,05)$. Nemaža studentų dalis (merginų 15\%, vaikinų $13 \%$ ) sportavimo pagrindine priežasti- 
4 pav. Atsakymų ị klausimą $A r J \bar{u} s$ mankštinatès, sportuojate? raiška tiriamųjų grupèse
5 pav. Atsakymų ị klausimą Ar Jūs nusiteikęs savarankiškai sportuoti, mankštintis ateityje? raiška tiriamųjų grupèse
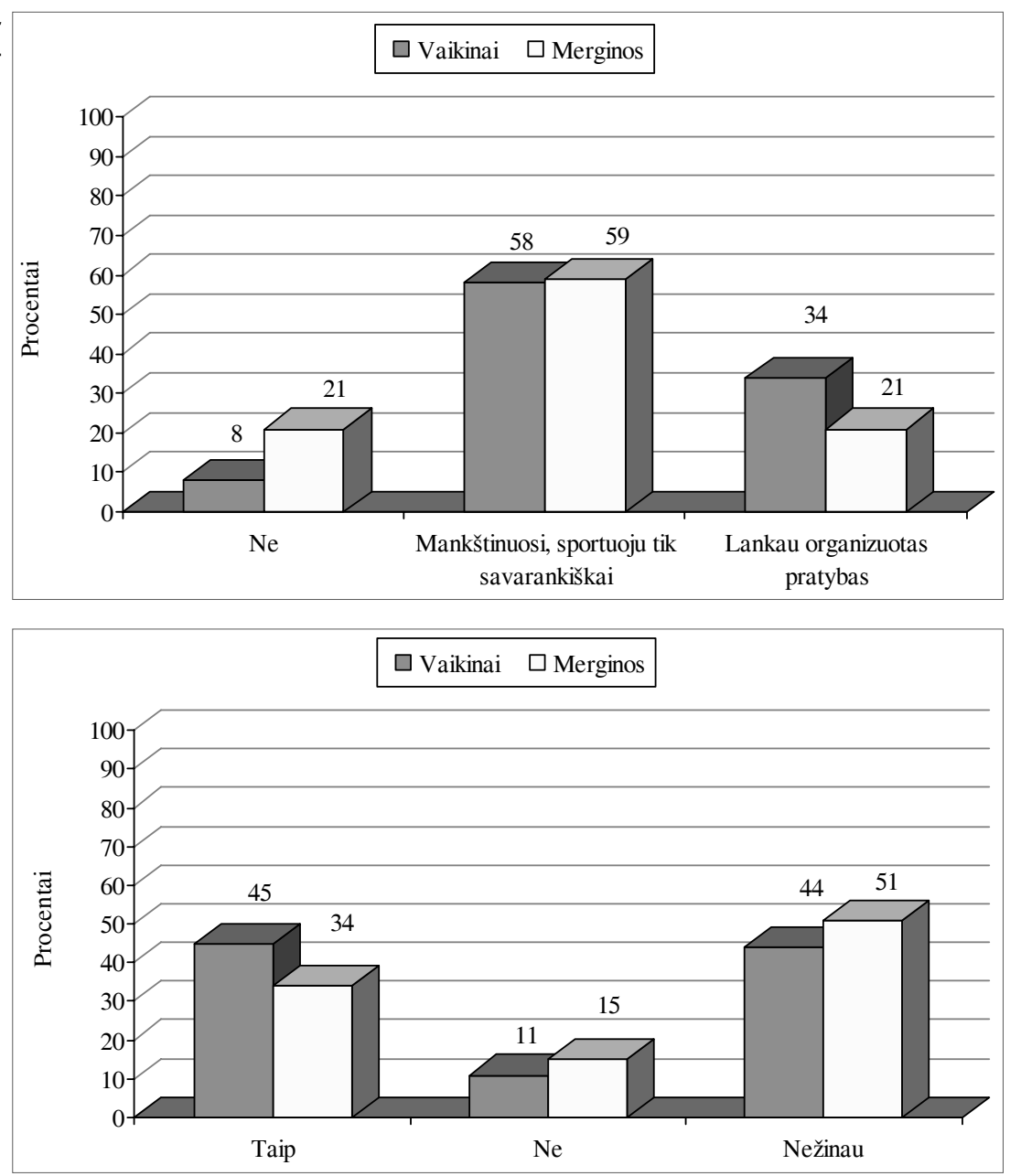

mi laiko norą stiprinti sveikatą ir likviduoti fizinio išsivystymo trūkumus. Fizini aktyvumą, kaip priemonę, padedančią atgauti dvasines jègas po itempto protinio darbo, laiko $11 \%$ merginu ir $14 \%$ vaikinų. Nustatytas labai mažas procentas studentų, siekiančiu puikių sportinių rezultatu (merginu $-3 \%$, vaikinu $-4 \%$ ).

Vertinant studentų atsakymus ì klausimą, kas paskatino sportuoti, matyti, kad išoriniai veiksniai turejo mažą itaką (4 lent.). Mokytoju paskatinti sportuoja tiktai $2 \%$ merginų ir vaikinų. Tèvų daroma įtaka yra taip pat maža. Vaikinu norą sportuoti daugiau lèmé draugu itaka $(8 \%)$, merginas tai paveikè mažiau $(5 \%)\left(\chi^{2}=12,03\right.$; $\mathrm{p}<0,05)$. Medicinos darbuotojų skatinimas labai mažai reikšmingas. Tiriamuosius daugiau sportuoti skatina vidiniai veiksniai, labiausiai - savarankiškas apsisprendimas, tačiau vaikinu šis rodiklis yra daug didesnis negu merginu $\left(\chi^{2}=168,88\right.$; $\mathrm{p}<0,05)$.

Iš apklaustu studentų dauguma (92\% merginu ir $91 \%$ vaikinų) pageidauja, kad pirmame kurse būtų laisvai pasirenkamos kūno kultūros praty- bos (5 lent.). Privalomų pratybų norètų mažuma studentų. Nusiteikusių sportuoti, mankštintis visą studiju laikotarpi buvo kur kas daugiau vaikinu $(45 \%)$ negu merginu $(34 \%)\left(\chi^{2}=24,49 ; \mathrm{p}<0,05\right)$ (5 pav.). Nežinančių, abejojančių, ar nori būti fiziškai aktyviais visą studiju laikotarpi, buvo kur kas daugiau merginu ( $51 \%$ ) negu vaikinu (44\%) $\left(\chi^{2}=9,87 ; \mathrm{p}<0,05\right)$.

\section{REZULTATŲ APTARIMAS}

Aukštesnèse klasėse vyrauja spartus moksleivių biopsichinio formavimosi etapas. I aukštąsias mokyklas įstoja studentai su tam tikromis nuostatomis, issitikinimais, motyvais, žiniomis, igūdžiais, elgsenos bruožais. Tai turi įtakos jų tolesnio gyvenimo būdui, psichofizinei raidai. Atliktas tyrimas parode, kad i VGTU pirmą kursą istoja vaikinai ir merginos, skirtingai vertinantys kūno kultūros vaidmeni jų gyvenime. Taip pat nustatytas skirtingas santykis su fiziniu aktyvumu, kaip viena iš studento veiklos sferų. Kadangi kūno kultūra, fizinès pratybos turi didelès 


\begin{tabular}{|c|c|c|c|c|c|}
\hline Kas paskatino sportuoti? & $\begin{array}{l}\text { Absoliučios ir pro- } \\
\text { centinės reikšmės }\end{array}$ & Vaikinai & Merginos & Iš viso & $\chi^{2}$ ir $\mathbf{p}$ reikšmès \\
\hline \multirow{2}{*}{ Nežinau } & n & 123 & 322 & 445 & \multirow{2}{*}{$\begin{array}{l}\chi^{2}=359,79 \\
p<0,05\end{array}$} \\
\hline & $\%$ & 8 & 38 & 18 & \\
\hline \multirow{2}{*}{ Tèvai } & $\mathrm{n}$ & 63 & 24 & 87 & \multirow{2}{*}{$\begin{array}{l}\chi^{2}=1,52 \\
p>0,05\end{array}$} \\
\hline & $\%$ & 4 & 3 & 4 & \\
\hline \multirow{2}{*}{ Mokytojai } & $\mathrm{n}$ & 28 & 16 & 44 & \multirow{2}{*}{$\begin{array}{l}\chi^{2}=0,15 \\
p>0,05\end{array}$} \\
\hline & $\%$ & 2 & 2 & 2 & \\
\hline \multirow{2}{*}{ Treneris } & $\mathrm{n}$ & 58 & 39 & 97 & \multirow{2}{*}{$\begin{array}{l}\chi^{2}=1,93 \\
p>0,05\end{array}$} \\
\hline & $\%$ & 4 & 5 & 4 & \\
\hline \multirow{2}{*}{ Draugai } & $\mathrm{n}$ & 134 & 38 & 172 & \multirow{2}{*}{$\begin{array}{l}\chi^{2}=12,03 \\
p<0,05\end{array}$} \\
\hline & $\%$ & 8 & 5 & 7 & \\
\hline \multirow{2}{*}{ Medicinos darbuotojai } & $\mathrm{n}$ & 31 & 30 & 61 & \multirow{2}{*}{$\begin{array}{l}\chi^{2}=6,46 \\
p<0,05\end{array}$} \\
\hline & $\%$ & 2 & 4 & 3 & \\
\hline \multirow{2}{*}{ Žiniasklaida } & $\mathrm{n}$ & 27 & 8 & 35 & \multirow{2}{*}{$\begin{array}{l}\chi^{2}=1,97 \\
p>0,05\end{array}$} \\
\hline & $\%$ & 2 & 1 & 1 & \\
\hline \multirow{2}{*}{ Jūs pats nusprendète } & $\mathrm{n}$ & 1115 & 360 & 1475 & \multirow{2}{*}{$\begin{array}{l}\chi^{2}=168,88 \\
p<0,05\end{array}$} \\
\hline & $\%$ & 71 & 43 & 61 & \\
\hline Iš viso & $\mathrm{n}$ & 1579 & 837 & 2416 & \\
\hline
\end{tabular}

\begin{tabular}{|c|c|c|c|c|c|}
\hline $\begin{array}{l}\text { Ar Jūs pageidautumète, kad } \\
\text { pirmame kurse būtų: }\end{array}$ & $\begin{array}{l}\text { Absoliučios ir pro- } \\
\text { centinès reikšmės }\end{array}$ & Vaikinai & Merginos & Iš viso & $\chi^{2}$ ir $\mathbf{p}$ reikšmès \\
\hline \multirow{2}{*}{ Privalomos pratybos } & $\mathrm{n}$ & 133 & 55 & 188 & \multirow{4}{*}{$\begin{array}{l}\chi^{2}=1,78 \\
p>0,05\end{array}$} \\
\hline & $\%$ & 9 & 8 & 9 & \\
\hline \multirow{2}{*}{ Laisvai pasirenkamos pratybos } & $n$ & 1315 & 678 & 1993 & \\
\hline & $\%$ & 91 & 92 & 91 & \\
\hline \multirow{2}{*}{ Iš viso } & $\mathrm{n}$ & 1448 & 733 & 2181 & \\
\hline & $\%$ & 100 & 100 & 100 & \\
\hline
\end{tabular}

5 lentelè. VGTU pirmo kurso studentų pageidavimas dèl kūno kultūros statuso itakos ne tik fizinès sveikatos būklès gerinimui (Grinienè, 2006), bet ir psichosocialinès sveikatos raidai (Nieman, 2002; Vainienè, Kardelis, 2008), fizinio aktyvinimo reikšmė aukštojoje mokykloje nemažeja. Svarbu formuoti studentu aktyvios fizinès veiklos poreiki. Tuo labiau, kad kūno kultūra padeda atsigauti po itempto protinio darbo (Kirjonen, 1991; Poteliūnienè ir kt., 2003; Tamošauskas, 2005). Tirti studentai skirtingai vertino kūno kultūros priemones, taikytas mokykloje. Vaikinams ši veikla patiko daug labiau negu merginoms, ir tai susiję su jų sumažejjusiu fiziniu aktyvumu. Tyrimai parodè, kad kūno kultūros mokytojų vaidmuo propaguojant sportą mokykloje yra didelis, tačiau mažai nuveikiama mokant moksleivius savarankiškai mankštintis, suteikiant teorinių žinių, formuojant specialiuosius igūdžius. Šios žinios turètų padèti geriau suvokti kūno kultūros ugdomają, sveikatinamaja, taikomają ir sportinę funkciją (Blauzdys, Vilkas, 2007). Istojus i aukštają mokyklą, kur organizuotos pratybos vyksta tik pirmame kurse, tenka taip tvarkyti mokymo procesa, kad studentai kuo daugiau igautu fizinès saviugdos žinių ir igūdžių (Dadelo, 2000; Poteliūnienè, 2001; Tubelis, 2001). Svarbu suformuoti studentu poreiki ir skatinti juos sportuoti laisvu nuo studiju metu (Tamošauskas, 2002; Poteliūnienè ir kt., 2003). Atliktas tyrimas parodé, kad daugiau merginu negu vaikinu pareiškè norą igyti žinių, tobulinti fizini aktyvumą. Šio tyrimo duomenys ryškiai skyrèsi nuo S. Poteliūnienès ir kt. (2003) gautujų, kuriais teigiama, kad 30,8\% tirtu Lietuvos aukštuju mokyklų studentų pageidavo privalomų kūno kultūros pratybų. Apklausti VGTU studentai beveik vieningai pareiškè norą, kad kūno kultūros pratybos būtų laisvai pasirenkamas dalykas. Tai rodo Lietuvos jaunimo savarankiškumo plètotès tendencijas, nes daugelis studentu pareiškè, kad jie savarankiškai sportuoja. Vaikinai šiai veiklai skiria kur kas daugiau laiko, dauguma iš ju lanko organizuotas fizines pratybas. Motyvai, skatinantys merginas ir vaikinus sportuoti, reikšmingai skiriasi, ir tai, ko gero, lemia prigimtinès jų savybès. Vaikinai nori būti fiziškai stiprūs, o merginos - turèti gražų kūną. Nemaža dalis studentų supranta sportavimo reikšmę sveikatos stiprinimui.

Studentų savarankiškumą parodè atsakymai i klausimą Kas paskatino sportuoti? Dauguma studentų atsakè, kad tai yra jų pačiu apsisprendimas. Taip atsakiusių vaikinu buvo kur kas daugiau 
negu merginu. Tuo tarpu kiti išoriniai veiksniai turejo labai mažą itaką. Yra pagrindo manyti, kad jaunimas darosi savarankiškesnis ir pats renkasi gyvensenos būdą ir kryptis. Lietuvos mokslininkai gana plačiai ištyrè fizinès saviugdos plètotę (Dadelo, 2000; Poteliūnienè, 2001; Tubelis, 2001). Parengta nemažai geros metodinès medžiagos, kaip reikia savarankiškai sportuoti teikiant savo organizmui biopsichinę naudą, kūno ir dvasinę gerovę. Tokie darbai išleisti pačiu laiku ir atitinka Lietuvos jaunimo raidos kryptis. Atliktas tyrimas parode, kad nusiteikusių būti fiziškai aktyviais visą studijų laikotarpi yra daugiau vaikinų nei merginų. Pirmame kurse kūno kultūros dèstytoju kūrybingas darbas dar daugiau turètu skatinti studentus ilgalaikei fizinei saviugdai, ir tam yra geros prielaidos.

\section{IŠVADA}

Daugumos į VGTU įstojusių studenčių ir studentų santykis su fiziniu aktyvumu yra skirtingas, ir tai patvirtina mūsų iškeltą hipotezę. Merginos ir vaikinai nevienodai vertina kūno kultūrą mokykloje. Merginų ir vaikinų motyvai sportuoti yra iš esmès skirtingi. Tyrimo metu išryškejjo studentu savarankiškumo didejjimo tendencijos, noras savarankiškai fiziškai mankštintis. Todẻl kūno kultūros pratybų organizavimas bei taikomi kūno kultūros ugdymo metodai vaikinams ir merginos turi skirtis. Išryškèja didelè stoka kūno kultūros teorinių žinių ir praktiniu igūdžių. Panaudojant atlikto tyrimo duomenis, gausią mokslinę metodinę medžiagą, atsiras geros sąlygos plètoti VGTU studentų fizini aktyvumą ir ypač jų fizinę saviugdą, teikti daugiau dalykinių ir metodinių žinių.

\section{LITERATŪRA}

Blauzdys, V., Vilkas, A. (2007) Kūno kultūros žinių poveikis gimnazijos mokinių fiziniam parengtumui. Ugdymas. Kūno kultūra. Sportas, 1 (64), 10-15.

Dadelo, S. (2000). Lietuvos teises akademijos studentu fizinis lavinimas taikant saviugda: disertacija. Vilnius: VPU.

Grinienè, E. (2006) Studentų savos sveikatos vertinimas ir požiūris į sveiką gyvenseną. Ugdymas. Kūno kultūra. Sportas, 1 (60), 10-17.

Kauffman, S. (2000). Investigations. Oxford: Oxford University Press.

Kirjonen, J. (1991). Personal values and motivation for exercise. Proceedings of the World Congress on Sport for All (pp. 413-421). Finland.

Laker, A. (2002). Culture, education and sport. In A. Laker (Ed.), The Sociology of Sport and Physical Education. An Introductory Reader. London and New York: Routledge Faimer. P. 1-14.

Nieman, P. (2002). Psychosocial aspects of physical activity. Paediatrics and Child Health, 7 (5), 309-312.

Poteliūnienè, S. (2001). Studenčiu, būsimu mokytoju, fizinès saviugdos edukacinis skatinimas: disertacija. Vilnius: VPU.

Poteliūnienė, S., Tamošauskas, S., Karoblis, P. (2003). Studentų požiūris ị kūno kultūros vyksmą Lietuvos aukštosiose mokyklose. Sporto mokslas, 4 (34), 54-59.

Prigogine, I. (1997). The End of Certainty. Time, Chaos and New Laws of Nature. New York: The Free Press.

Puišienè, E., Kardelienè, L, Kardelis, K. (2008). Kauno miesto vyresniuju klasių vaikinų ir merginų gyvensenos skiriamieji bruožai. Ugdymas. Kūno kultūra. Sportas, 1 (68), 73-79.

Skernevičius, J., Raslanas, A., Dadelienè, R. (2004). Sporto mokslo tyrimu metodologija. Vilnius: Lietuvos sporto informacijos centras.

Tamošauskas, P. (2005). Interrelation of academic physical training and Olympic education. Acta Academiae Olympiquae Estoniae, 13, 1, 12-26.

Tamošauskas, P. (2002). Olimpizmas ir studentu kūno kultūra. Ugdymas. Kūno kultūra. Sportas, 2 (43), 6672.

Tamošauskas, P., Poteliūnienė, S., Karoblis, P., Poviliūnas, A. (2004). Studentų fizinis ugdymas Lietuvos aukštosiose mokyklose humanistinès pedagogikos kontekste. Sporto mokslas, 2 (36), 68-73.

Tamošauskas, P. (2006). Veiksniai, lemiantys kūno kultūros raidą Lietuvos universitetinèse aukštosiose mokyklose XXI a. iššūkių kontekste. Sporto mokslas, 4 (46), $2-7$.

Tubelis, L. (2001). Studentu fizinès saviugdos skatinimo sistema ir jos efektyvumas: disertacija. Vilnius: VPU.

Vainienė, E., Kardelis, K. (2008). Jaunimo mokyklų moksleiviu fizinio aktyvumo sąsajos su mokymosi motyvacija, savigarba ir socialine integracija. Ugdymas. Küno kultūra. Sportas, 1 (68), 100-109.

Wilmore, J., Costill, D. (1994). Physiology of Sport and Exercise. Human Kinetics.

Платонов, В. (1988). Адаптациия в спорте. Киев. C. $30-71$. 


\title{
SPECIFIC FEATURES OF ATTITUDE TO PHYSICAL EDUCATION EXHIBITED BY THE FIRST YEAR STUDENTS AT VILNIUS GEDIMINAS TECHNICAL UNIVERSITY
}

\author{
Stanislavas Dadelo, Povilas Tamošauskas, Valda Morkūnienė, Daiva Višinskienė \\ Vilnius Gediminas Technical University, Vilnius, Lithuania
}

\begin{abstract}
Inquiry into the attitude to and relation with physical education exhibited by the first year students (girls and boys) enrolled at Vilnius Gediminas Technical University as well as the determination of distinctive gender-specific characteristics will facilitate more effective organisation and optimisation of physical training which will produce a favourable influence on students' physical activity and develop a need for systematic physical activation. The purpose of the research was to evaluate the attitude to and the relation with physical education demonstrated by VGTU first year students, and to reveal relevant distinctive characteristics exhibited by girls and boys.

Research involved 2181 first year students aged 19-20 years who were enrolled at VGTU in 2007 (733 girls and 1448 boys). The sample under study covered $73 \%$ of total number of the population. The study participants were selected at random. The study was based on a fill-in questionnaire survey technique. The questionnaire included 10 questions supplied with relevant answer options. Part of the questions were closed (only one answer option could be selected), the rest of the questions were open (several answer options could be selected and one's own option could be added).

The survey was carried out on the grounds of the principles of anonymity and provision of information about the research purpose and procedure. Most VGTU male and female first year students exhibited different gender-specific characteristics of relation to physical activity, which supported our hypothesis. The girls and the boys gave different evaluation to physical education measures applied at the university. They demonstrated essentially different motives for getting engaged in sports. A tendency towards the growth of students' independence and a desire to train independently was observed. Thus, different interaction and physical education development methods must be applied to girls and boys. Huge deficiency of theoretical knowledge and practical skills in the area of physical education was revealed. The findings of this research as well as rich scientific methodological material offer good premises for the development of physical activation and especially the much-desired physical self-development among VGTU students, and for the provision of a larger volume of subject-related methodological information.
\end{abstract}

Keywords: attitude to physical education, physical activity, separate training. 